\title{
Physical-mechanical behavior of fresh and completely altered rocks as an important factor of slope instability in the El Rosario Monarch Butterfly Sanctuary, Michoacán, Mexico
}

\section{Juan Manuel Sánchez-Núñez ${ }^{1 *}$, Antonio Pola², Guillermo Cisneros ${ }^{3}$, Hugo Iván Sereno², María Elena Serrano-Flores ${ }^{1}$, Luis Ángel Jiménez ${ }^{4}$, and Perla Rodríguez ${ }^{5}$}

\author{
${ }^{1}$ Instituto Politécnico Nacional, Centro Interdisciplinario de Investigaciones y Estudios sobre Medio Ambiente y Desarrollo (CIIEMAD), \\ calle 30 de junio de 1520, La Laguna Ticomán, C.P. 07340, Mexico City, Mexico. \\ ${ }^{2}$ Unidad de Petrofísica, Escuela Nacional de Estudios Superiores-Unidad Morelia, Universidad Nacional Autónoma de México, \\ Antigua Carretera a Pátzcuaro 8701, C.P. 58190, Morelia, Michoacán, Mexico. \\ ${ }^{3}$ Instituto de Geofísica, Universidad Nacional Autónoma de México, Campus Morelia, \\ Antigua Carretera a Pátzcuaro 8701, C.P. 58190, Morelia, Michoacán, Mexico. \\ ${ }^{4}$ Instituto Politécnico Nacional, Posgrado del Centro Interdisciplinario de Investigaciones y Estudios sobre \\ Medio Ambiente y Desarrollo (CIIEMAD), calle 30 de junio de 1520, La Laguna Ticomán, C.P. 07340, Mexico City, Mexico. \\ ${ }^{5}$ Instituto de Ingeniería y Tecnología, Universidad Autónoma de Ciudad Juárez, \\ Av. del Charro 450, Colonia Partido Romero, C.P. 32310, Ciudad Juárez, Mexico. \\ *jsancheznu@ipn.mx
}

\begin{abstract}
Slope instability in the Butterfly Biosphere Reserve (RBMM) Michoacán, Mexico, is a widespread phenomenon that results from the complex interaction among different factors such as climate, slope, and the spatial distribution of different rock units. The climate is temperate subhumid, with rains in summer and an annual average rainfall of 700 to $1250 \mathrm{~mm}$. The main physiographic units of the area are volcanic mountains, with slopes greater than 30 degrees. The main scope of this study is to characterize the physical-mechanical properties of fresh and completely altered lower Miocene andesitic lavas of the Sierra de Angangueo (Cerro El Campanario, province of El Rosario, Michoacán) by implementing laboratory tests (bulk density, permeability, porosity, uniaxial compressive strength). The fresh rock sample presents total porosity, permeability, and UCS values of $0.262 \mathrm{mD}, 17.1 \%$, and $63.5 \mathrm{MPa}$, respectively. Instead, the altered rock display values of $393.71 \mathrm{mD}, 60.9 \%$, and $0.26 \mathrm{MPa}$. Our results suggest that the slope and the degradation of the rock properties induced by alteration are the conditioning factors of instability in the region. Atypical rainfalls may act as triggering mechanism for slope failure.
\end{abstract}

Key words: Physical-mechanical behavior; fresh rock; altered rock; El Campanario; Monarch Butterfly Sanctuary; Michoacán; Mexico.

\section{RESUMEN}

La ocurrencia de fenómenos de inestabilidad de ladera dentro de Reserva de la Biosfera de la Mariposa Monarca (RBMM) Michoacán, México son muy frecuentes, básicamente porque existe la interacción de diferentes factores como el clima, la pendiente y la distribución espacial de las diferentes unidades de roca. El clima es de tipo templado subhúmedo con lluvias en verano y una precipitación promedio anual desde 700 hasta $1250 \mathrm{~mm}$, mientras que la principal unidad fisiográfica de la zona son las sierras volcánicas, que presentan una pendiente mayor a 30 grados. El objetivo principal de este estudio es la caracterización de las propiedades físico-mecánicas de lavas andesíticas frescas y completamente alteradas del Mioceno inferior de la Sierra de Angangueo (cerro El Campanario, provincia de El Rosario, Michoacán), con base en la implementación de una serie de pruebas de laboratorio (densidad, permeabilidad, porosidad, compresión uniaxial). En general existe un contraste evidente entre las propiedades. La muestra de roca fresca presenta una porosidad total, una permeabilidad y un valor de resistencia (UCS) igual a $0.262 \mathrm{mD}$, $17.1 \%$ y $63.5 \mathrm{MPa}$, respectivamente, mientras que la roca totalmente alterada presenta valores iguales a $393.71 \mathrm{mD}, 60.9 \%$ y $0.26 \mathrm{MPa}$. Los resultados del presente estudio en conjunto sugieren que la pendiente $y$ la degradación de las propiedades de la roca por alteración son factores condicionantes de inestabilidad en la región. Factores externos como la precipitación pluvial atípica pueden actuar como factor desencadenante de procesos de remoción en masa.

Palabras clave: comportamiento físico-mecánico; roca fresca; roca alterada; El Campanario; Santuario de la Mariposa Monarca; Michoacán; México.

\section{INTRODUCTION}

Landslides represent a major socio-economic impact in most world countries, they are responsible for direct and indirect costs as well as for the loss of human lives and ecosystems damage in most mountainous and hilly regions of the world (Nadim et al., 2006; Dikau et al., 1996). The causes of landslides are differentiated into two categories: the triggering factors and the conditioning (susceptibility) factors.

Sánchez-Núñez, J.M., Pola, A., Cisneros, G., Sereno, H.I., Serrano-Flores, M.E., Jiménez, L.Á., Rodríguez, P., 2021, Physical-mechanical behavior of fresh and completely altered rocks as an important factor of slope instability in the El Rosario Monarch Butterfly Sanctuary, Michoacán, Mexico: Revista Mexicana de Ciencias Geológicas, v. 38, núm. 3, p. 272-282. 
The most common natural landslide triggers include intense rainfall, water-level change, volcanic eruption, and earthquakes. These factors cause an immediate reaction by increasing the stress or strains and reducing the strength of the slope materials. Rainfall is one of the most important triggering factors of landslides (Wieczorek, 1987; Saucedo et al., 2008; Persichillo et al., 2016; Mikoš et al., 2017).

The landslide occurrence varies according to different conditioning factors such as geology, tectonic history, topographic profile, weathering, and erosional history (Varnes, 1978). The conditioning factors are the internal terrain elements susceptible to generating a landslide due to a stimulating factor that modifies the slope condition. The hydrothermal alteration of rocks is an important precursor to landslides and is considered a conditioning factor. However, also hydrothermally altered areas can become a triggering factor (Reid et al., 2001, Maeda et al., 2012).

Rock properties are essential for slope stability, and they are fundamental aspects of geological hazards. The progressive alteration of rocks and the changing properties promote a range of geological phenomena as slope instability and rock failure with the triggering of different landslide types (Aladejare and Wang, 2016; Frolova et al., 2019). In the following, we indicate some examples that show the importance of carrying out a characterization of the geomechanical properties of both fresh and totally altered rock to study the generation of landslides. Frolova et al. (2019) studied the alteration of volcanic rocks and changes in the physical-mechanical properties of the South-Kambalny thermal field (Kamchatka). They concluded that, under the influence of thermal water, the changes in the mineral composition of the original rocks gradually modify to clays and secondary minerals; these transformations promote landslides. The geotechnical characterization of crater wall sequences at White Island Volcano, New Zealand (Moon et al., 2005) showed that hydrothermally altered rocks (andesite) exhibit considerable loss of strength, essentially frictional resistance, compared with the fresh lava units. An important study carried out by Reid et al. (2001) deals with large collapses of hydrothermally altered parts of Mount Rainier (Cascade Range) that generated far traveling debris flows. As part of their methodology, they used a three-dimensional gravitational slope stability tool and mapped the distribution of fresh and altered rocks to analyze the potential volcano instability. They conclude that weakening of edifice rocks by hydrothermal alteration could be important for promoting and localizing the flank collapse.

The above examples show that rock alteration processes are an important factor for slope instability. However, other phenomena such as rainfall that could trigger landslides should also be considered. An example for these conditions is the study carried out by Kim and Song (2015) in South Korea. They analyzed three types of rocks (sedimentary, metamorphic, and igneous) to determine the geotechnical characteristics of landslides under various geological conditions using laboratory test, field surveys and precipitation records. They highlight that rock alteration, rainfall, and the slope of the terrain between 26 and 30 degrees are important factors for slope failure.

In the year 2010, in Mexico occurred extraordinary rainfall in the region of the Sierra Angangueo, Michoacán which is the site of the Monarch Butterfly Sanctuaries. This atypical rainfall produced mass movements in the Sierra de Angangueo. These failures generated several debris flows that impacted the municipality of Ocampo. They caused at least 31 casualties and infrastructure damages throughout the region (Alcántara-Ayala et al., 2012).

In this study, we analyzed the physical-mechanical properties of andesitic rocks that sourced debris flow in the Monarch Butterfly Sanctuary, which belongs to the municipality of Ocampo. We collected samples of fresh and altered andesites and analyzed them in the laboratory to define their mechanical properties. The objective of this study is to know how the hydrothermal alteration diminished the strength of rocks, facilitating the generation of debris flows.

\section{STUDY AREA AND GEOLOGICAL SETTING}

The study area is located in the south-central part of the TransMexican Volcanic Belt (TMVB) (Figure 1a) in the Mil Cumbres physiographic subprovince (INEGI, 2009), within the municipality of Ocampo, located in the northeast of the state of Michoacán between parallels $19^{\circ} 35^{\prime}$ and $19^{\circ} 41^{\prime} \mathrm{N}, 100^{\circ} 14^{\prime}$ and $100^{\circ} 22^{\prime} \mathrm{W}$. This municipality limits to the north with the municipalities of Aporo and Angangueo, to the south with the municipality of Zitácuaro, to the west with the municipality of Tuxpan, and to the east with San José del Rincón, belonging to the state of Mexico.

More locally, the study area lies within the Sierra Angangueo, a NNW-SSE elongated landform that represents the most important morphotectonic feature of the region (Figure 1b). El Campanario hill, with an elevation $3640 \mathrm{~m}$ a.s.l., is the highest peak of the Sierra de Angangueo and is the main sanctuary of the Monarch Butterfly Biosphere Reserve (MBBR), located nearby the El Rosario locality (Figure 1c, 2). The hydrothermal alteration zone in El Campanario hill is associated with the mineral deposits of the Angangueo Mining District (Ostrooumov, 2014; Hernández-Bernal et al., 2016). This alteration process was correlated with the 2010 landslides that partly swept the town of Angangueo, Michoacán (López-García and Alcántara-Ayala, 2012).

The basement in the region is represented by Upper Jurassic to Lower Cretaceous rocks of the Guerrero Terrain (151-140 Ma) (Campa and Coney, 1983). The oldest exposed rocks in the area are of Lower Cretaceous age and correspond to a metamorphosed sequence of andesite and volcano-sedimentary sediments interstratified with metalimestone, metalutites and metasandstone (Campa et al., 1981; Campa and Coney, 1983). On top of these old lithological successions, the volcanic rocks of Sierra de Angangueo are exposed (Pasquaré et al., 1991; SGM, 2000; Ferrari et al., 2012; Hernández-Bernal, 2016). The Sierra de Angangueo is made of three volcanic successions emplaced during the early-middle Miocene. They consist of massive andesite lava flows and several andesitic cones aligned in a NNW-SSE direction.

The oldest volcanic unit in Sierra de Angangueo (Lamt) is the most widespread rock in the study area and consists of several volcanic cones of andesitic composition, dated between 23.9 and $13 \mathrm{Ma}$ (HernándezBernal et al., 2016). The Lamt is covered by Quaternary basaltic lavas (Abpl), which in turn is covered by alluvium and piedmont sediments that represent the youngest deposits (Figure 2). From a structural point of view, in the Sierra Angangueo predominates a NNW-SSE fault system formed during the Laramide Orogeny in Late Cretaceous to early Paleocene times (Demant, 1978; SGM, 2000). According to SGM (2000), H. Ayuntamiento Constitucional de Angangueo, Michoacán (2014), and Hernández-Bernal et al. (2016) the study area is affected by three successive structural systems that are: a NW-SE system (from $300^{\circ}$ to $340^{\circ}$ ), a NE-SW system (e.g. El Rosario fault of $c a .40 \mathrm{~km}$ length), and an E-W system (Morelia-Acambay) that cuts the El Rosario fault (Figure 2b). Faults and fractures of these structural systems affected the stratigraphic succession in the Sierra de Angangueo, generating weak areas in the lithological units.

\section{METHODOLOGY}

To produce the geological map and the Digital Terrain Model (DTM) of the MBBR and Sierra de Angangueo areas, we combined the digital topography of $5 \mathrm{~m}$ contour lines of the Instituto Nacional 


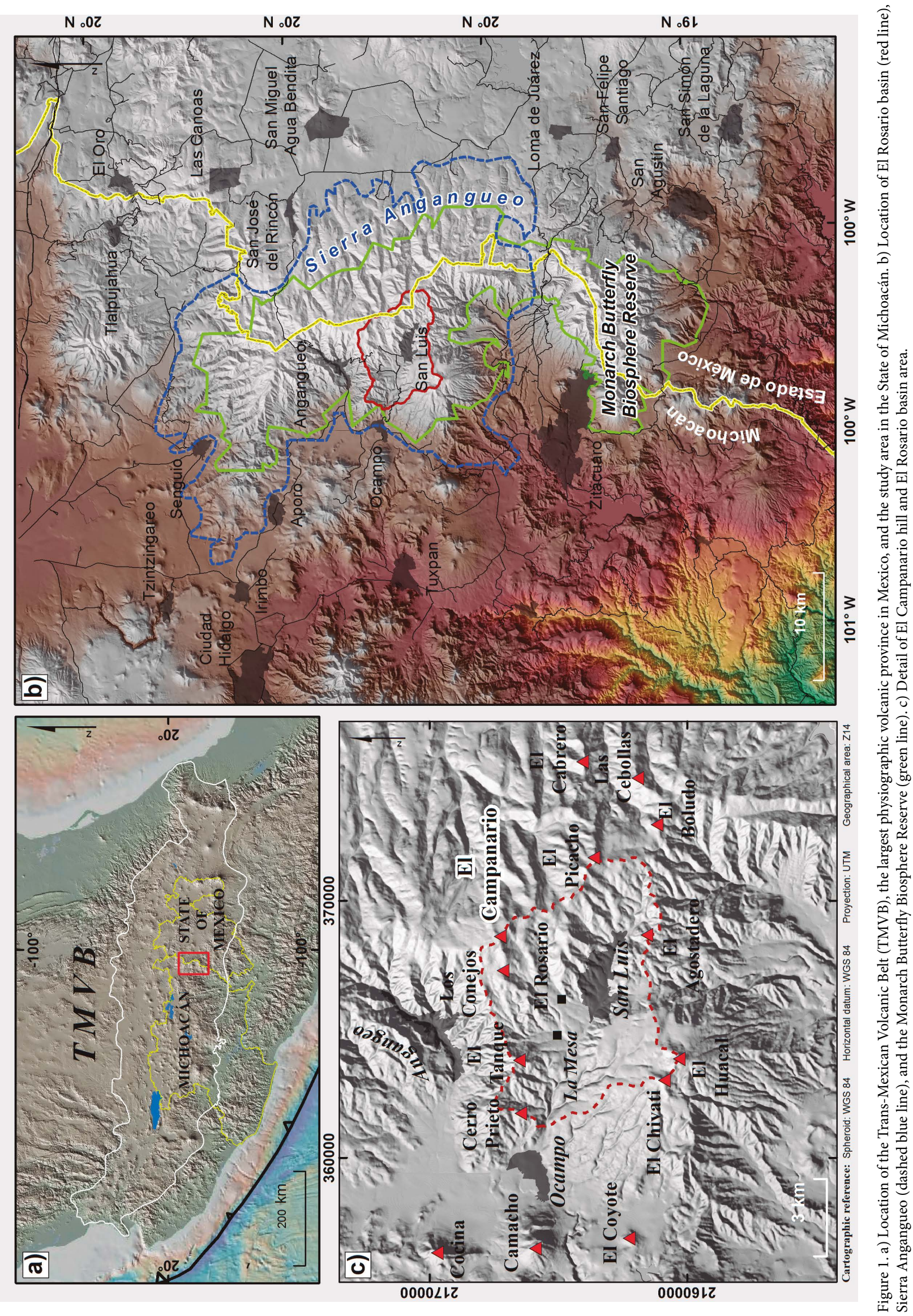



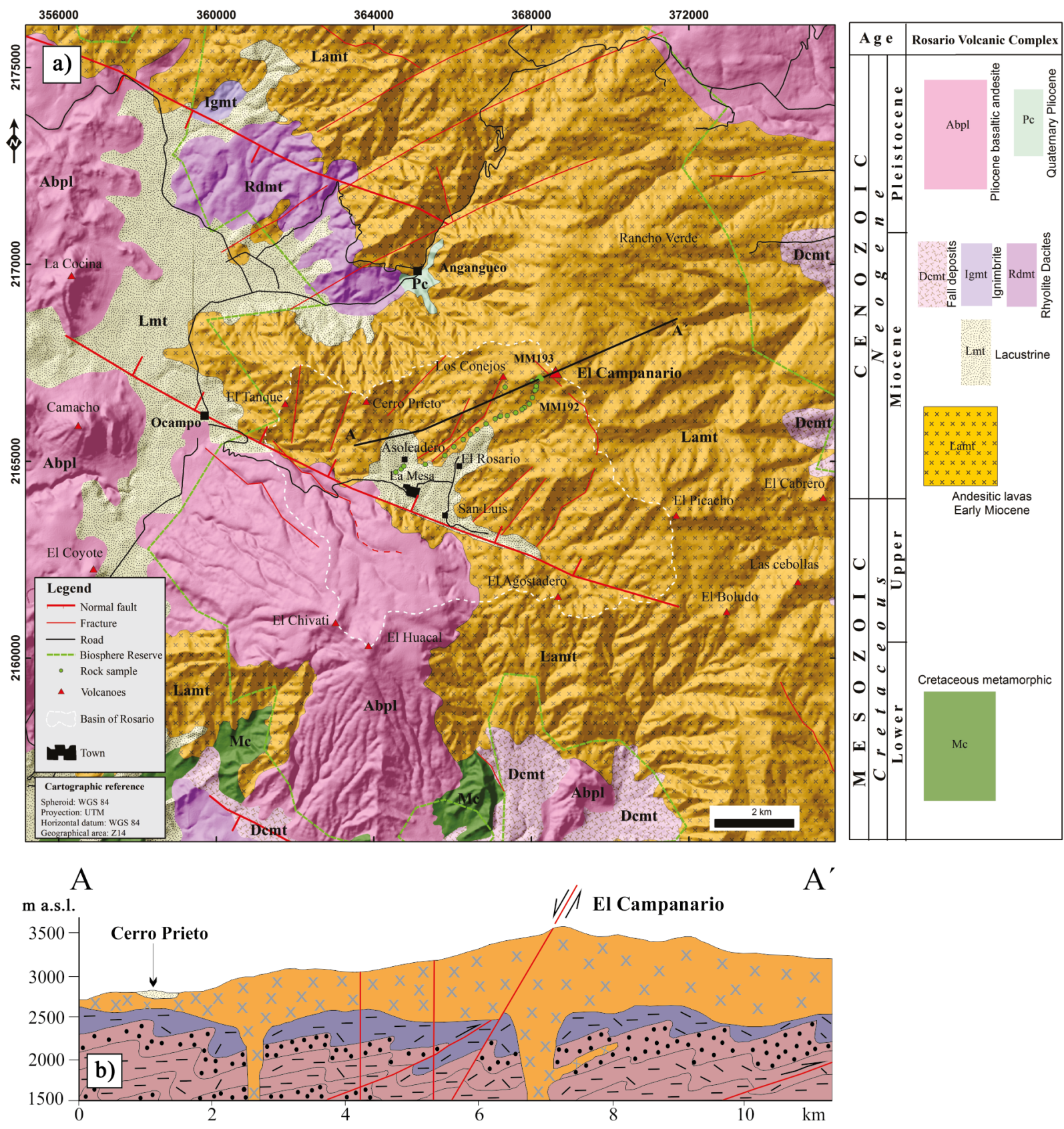

$\mathrm{A}^{\prime}$

Figure 2. a) Simplified geological map of the El Campanario hill area, located to the northeast of the Monarch Butterfly Biosphere Reserve (modified from Hernández-Bernal et al., 2016). b) ArcGis profile (A-A') showing the andesitic lavas at the El Campanario hill covering the metamorphic basement in the Sierra de Angangueo (modified from SGM, 2000).

de Estadística y Geografía (INEGI), and the $12.5 \mathrm{~m}$ contour lines of the Alaska Satellite Facility (ASF) (UAF-NASA). The DTM and map are georeferenced with respect to the WGS-1984-UTM-Zone-14N coordinate system. The resulting DTM was used to prepare shaded relief models and an anaglyph. We used Landsat TM8 images, panchromatic ( $15 \mathrm{~m}$ resolution), multispectral ( $30 \mathrm{~m}$ resolution), and Spot- 6 satellite images (1.5-m panchromatic and 6-m multispectral resolutions). For the construction of thematic maps (slopes, dissection, and altitude) we obtained a DTM with $15 \mathrm{~m}$ resolution (INEGI, 2010). This information was edited in ArcGis 10.2 Base Map, the Google Earth imagery server, and using vectorial cartography (e.g. geographic limits, urban infrastructure, roads, and towns).

\section{Sampling procedure}

All physical and mechanical laboratory tests were performed according to international standards to place our results in an international context as follows: We collected two samples according to the distribution of rock units and slope stability phenomena. As shown in Figure 3, the fresh sample (MM193) was collected atop the El Campanario hill. The sample was in situ, away from the collapse zone, without fractures, with a minimum of discontinuities and avoiding metamorphic or weathered areas. The minimum dimensions of the sample were $30 \times 30 \mathrm{~cm}$. The completely altered rock sample (MM192) was collected in situ, on the southern flank of El Campanario hill, on the slip plane, near the fault scarp and the collapse zone. The minimum 

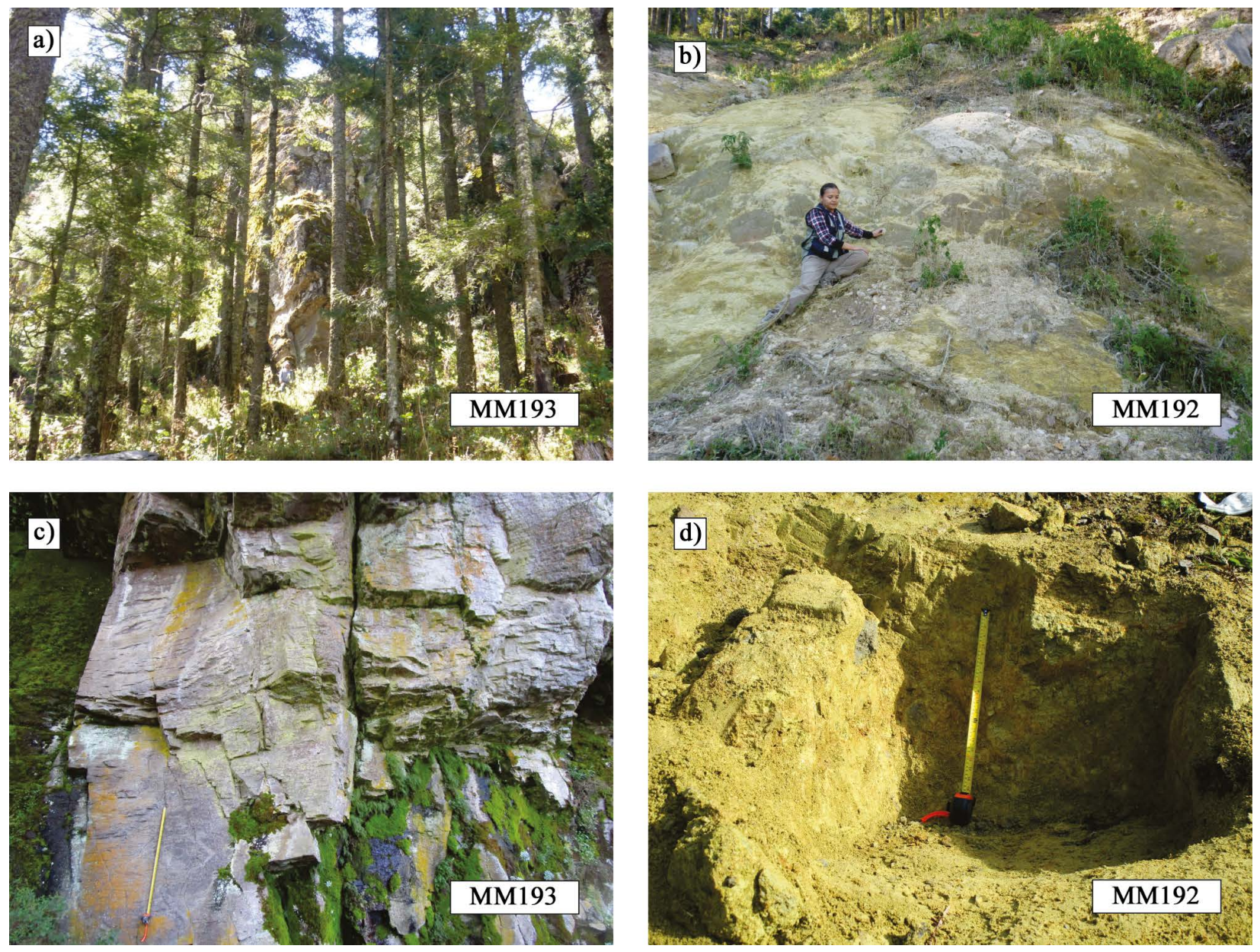

Figure 3. a) and b) Panoramic view of the outcrops at Monarch Butterfly Biosphere Reserve. c) MM193 outcrop where fresh sample was collected. d) MM192 outcrop where completely altered sample was collected.

sample dimensions were $30 \times 30 \mathrm{~cm}$ (Table 1 ). The ID (identification tag) of samples corresponds to the outcrop number, composed by the first letters of the name of the project, followed by a sequential numbering. To perform a detailed geomechanical characterization, we collected two blocks of fresh and two blocks of altered rocks of different dimensions $(\sim 30 \times 30 \times 30 \mathrm{~cm})$. We segmented each block into twentyfive specimens (cylinders and discs of 53,32 , and $25 \mathrm{~mm}$ in diameter) (ASTM D4543-01; ASTM, 2001a) and verified with normalized tools, including the Specimen Flatness Gauge. Cylindrical specimens of altered rock (MM192) could not be extracted and prepared by Core Drilling because the material was very soft. Instead, we, prepared this sample with a lathe, trimmer, and extruder apparatus used to prepare cylindrical soil samples, by taking a mold of a cylindrical specimen of $53 \mathrm{~mm}$ in diameter by $90 \mathrm{~mm}$ in height.

General characteristics of the outcrops and hand specimen are described as follows: The MM192 ochre to yellow outcrop is located in the southern flank of the "El Campanario" hill. It is about 10-m thick. Samples were collected at the slope instability surface that generated a debris flow (Figure $3 a$ and $3 b$ ). The entire rock mass was classified as Disintegrated being completely transformed, broken with a mixture of fine grains and angular to rounded rock fragments (Figure 3d). Some silica refilled or recrystallized fractures are observed. In hand specimen, the rock is massive, strongly hydrothermally altered, with plagioclase phenocrysts and pyroxene in minor proportion. At outcrop scale, the entire rock was water-saturated with runoff features.
The MM193 outcrop consists of a sequence of lava flows ( $\mathrm{ca} .150 \mathrm{~m}$ thick) located at the top of the El Campanario hill (Figure 3a and 3c). The color of the rock changes along the outcrop, from gray and brown to ochre yellow in the most altered part. The entire rock mass could be classified as Very blocky: is partially disturbed with multifaceted angular blocks (e.g., wedge-shaped) formed by at least three sets of discontinuities, some of them produced by the cooling process. The hand specimen could be described as massive with porphyritic texture containing plagioclase, pyroxene, and amphibole in minor proportion (Figure 3c).

\section{Physical and petrological characterization}

We determined the particle density or real density $(\rho)$ (i.e., the specific gravity of a material) and the bulk density $(\gamma)$ (i.e., the mass of a material divided by the total volume). The $\rho$ of each sample was

Table 1. Sample characteristics of rock analyzed from El Campanario hill at Monarch Butterfly Biosphere Reserve, Sierra Angangueo, Mexico.

\begin{tabular}{lcccl}
\hline \multirow{2}{*}{ Sample ID } & \multicolumn{3}{c}{ Coordinates (UTM) } & \multirow{2}{*}{ Description } \\
\cline { 2 - 4 } & $\mathrm{X}$ & $\mathrm{Y}$ & $\mathrm{Z}$ (m a.s.1.) & \\
\hline \multirow{2}{*}{ MM192 } & 368261 & 2167090 & 3433 & Altered andesite \\
MM193 & 368211 & 2167146 & 3496 & Fresh andesite \\
\hline
\end{tabular}


defined with a Quantachrome 1200e pycnometer designed to measure the true volume of solid materials by fluid displacement and gas expansion (Boyle's Law). Ultra-high purity helium (99.999\%) is used as the displacing fluid since it penetrates the finest pores assuring maximum accuracy (ASTM D5550-14; ASTM, 2014). The $\gamma$ was obtained with basic methods (e.g., water saturation) (ASTM D7263-21; ASTM, 2021). A major issue was to obtain an accurate estimate of the total volume of the rock sample. Different methods for calculating the $\gamma$ of a material are used based on how the void space in the samples is handled (see ASTM D7263-21) for a good review).

The Porosity $(\eta)$ of rock includes pores, cracks, and inter- and intra-crystalline spaces, and varies between 0 and 1 . Porosity keeps a close relation with strength, strain and hydric properties depending on the rock type and grain arrangements (grain size and distribution, grain packing, particle shape). Total porosity $\left(\eta_{t}\right)$ considers the total porous volume regardless of whether they are interconnected or not, and effective porosity $\left(\eta_{\mathrm{e}}\right)$, is the interconnected portion of the total void space allowing the circulation of fluids. General characteristics of the pore structure (e.g., pore size distribution and porosity) are related to mechanical properties (e.g., compressive strength, modulus of elasticity and Poisson ratio), as well as hydric characteristics (e.g., capillarity and permeability).

Effective porosity $\left(\eta_{\mathrm{e}}\right)$ was obtained following the procedure recommended by ISRM (2007) employing a vacuum water saturation test. Samples were oven dried at a temperature of $70^{\circ} \mathrm{C}$ for 48 hours until a constant mass was achieved. The dried samples were placed in a vacuum at $20 \pm 7$-mbar pressure in three 5-hour cycles. As described in the European standard EN 1936:2006 (EN, 2006), the trapped gases in the porous system were eliminated during the first cycle. During the second cycle, samples were slowly introduced into distilled water over 15 minutes until they were submerged $5 \mathrm{~cm}$ in water. The samples were submerged for 5 hours. Atmospheric pressure was re-established and maintained throughout the last cycle. Thus, connected porosity is defined as the measure of the void spaces in a material (ratio of absorbed water to water density), and is a fraction of the volume of voids over the total volume, expressed as a percentage.

\section{Hydric characterization}

Permeability $(k)$ is a measure of how readily a fluid can flow through a porous material and it is a property inherent to the material which does not depend on the type of fluid used to measure it. Permeability depends on intrinsic properties including porosity, pore size, pore-size distribution, pore connectivity, and tortuosity. Permeability $(k)$ test was carried out following standard procedures (ASTM D4525-13e2; ASTM, 2013) and those described in the literature (Sander et al., 2017). Permeability values were measured by using a GasPerm AP-123-002-0 gas permeameter, designed for the determination of permeability to gas at steady state condition (constant pressure and flow through the sample). In general terms, $k$ is obtained by the injection of nitrogen ( $99.999 \%$ high purity) at flowrate $Q$ and pressure $P$ through a confined cylindrical rock specimen. The confining pressures range from 300 to $400 \mathrm{psi}$, while flow rate range from 0 to $600 \mathrm{~cm}^{3} / \mathrm{min}$. Initial flow rate and differential pressure during the test are subjected to the characteristics of each rock type and the length of the specimens. Results were collected by applying the law of Darcy for ideal horizontal laminar flow of gas under steady state isothermal conditions. To account for the Klinkenberg effect (gas permeability of a core is always higher than its permeability to a single saturating inert liquid), we constructed a graph. Here, if the gas permeability values obtained at different mean core pressures are plotted against reciprocal mean pressure $\left(1 / P_{\mathrm{m}}\right)$ a straight line should fit the points (frequently five). Finally, the liquid permeability is obtained by the extrapolation of this line to infinite mean pressure where it intersects the gas permeability axis. The spatial location of these five points and the slope of the trend line are directly related to the distribution of pore sizes and the morphology of the entire system.

\section{Mechanical characterization}

The mechanical behavior of a rock material directly depends on its physical properties (e.g., Heap and Kennedy, 2015; Bubeck et al., 2017) and it shows a strong link with porosity (an increase in porosity or pore size is typically associated with a decrease in strength), the distribution of the minerals and pores, and the fracture content and arrangement (the relative orientation of the applied load and fracture plane).

Uniaxial compressive tests and splitting tensile tests were performed following standard procedures ASTM D2938-95(2002) (ASTM, 2002a), D3148-02 (ASTM, 2002b), ASTM D3967-95a(2001) (ASTM, 2001b), using a Geotechnical Digital Virtual Infinite Stiffness Loading System (250 kN GDS VIS) at a constant displacement rate of $4 \mathrm{~mm} / \mathrm{h}$. Stress and strains were recorded continuously during each test by two load cells (internal [inside the load cell] and external [integrated into the compression ring]). The elastic properties (Young's modulus and Poisson's ratio) were obtained by recording local deformations through the use of three Linear Variation Differential Transformers (LVDT), two axial and one radial.

\section{RESULTS}

Through physical and mechanical laboratory tests, we determined that the instability factors are directly related to the alteration of the rocks and the changes in their physical-mechanical properties. Other conditioning factors in the study area are steep slopes, altimetry, and geometry of the terrain that were determined with photo interpretation techniques, digital images, and relief analysis.

Figure 4a shows the regional landform conditions in a hypsometric map of the El Rosario basin. We observe that El Campanario hill is the most prominent elevation of the basin (yellow circle). Figure $4 \mathrm{~b}$ shows the slope map in which the steeper slopes in the area occur near the top of the hill (black circle). Figure 4c (2005 satellite image) shows a close-up on El Campanario hill before the slope failure. We observe the hillside with undisturbed vegetation. The white dotted line shows the collapse area and the direction followed by the displaced material. Figure 4d shows a satellite image (2015) after the slope failure. The extension of the debris flow deposit to the SW of El Campanario hill has a straight to convex geometry from and a steep slope near the scarp. Additionally, we observe the debris flow source area, the scarp, and the rock alteration zone located at $3475 \mathrm{~m}$ a.s.l. with a slope gradient $>35^{\circ}$. The toe of the debris flow deposit occurs at $2988 \mathrm{~m}$ a.s.l. with a slope gradient of $<10^{\circ}$.

About the rainfall in the study area, the rain records from five meteorological stations near the Monarch Butterfly Biosphere Reserve indicate that data from 2010 were atypical (Figure 5). As a result, the National Water Commission (Comisión Nacional del Agua) declared several municipalities as disaster area in Michoacán (DOF, 2010). Figure 5a shows the rainfall in February from four hydrometeorological stations in the Sierra de Angangueo, highlighting the Chilesdo station with $312.4 \mathrm{~mm}$ of precipitation in 2 days. In turn, Figure 5b shows the historical record of the Chilesdo station, clearly showing an anomalous value in 2010. Alcántara-Ayala et al. (2012) pointed out this atypical precipitation with cumulative rainfall values (more than $144 \mathrm{~mm}$ in one day).

Based on our field survey we identified the area affected by landslides during the February 2010 rainfall. The area exposes fresh 

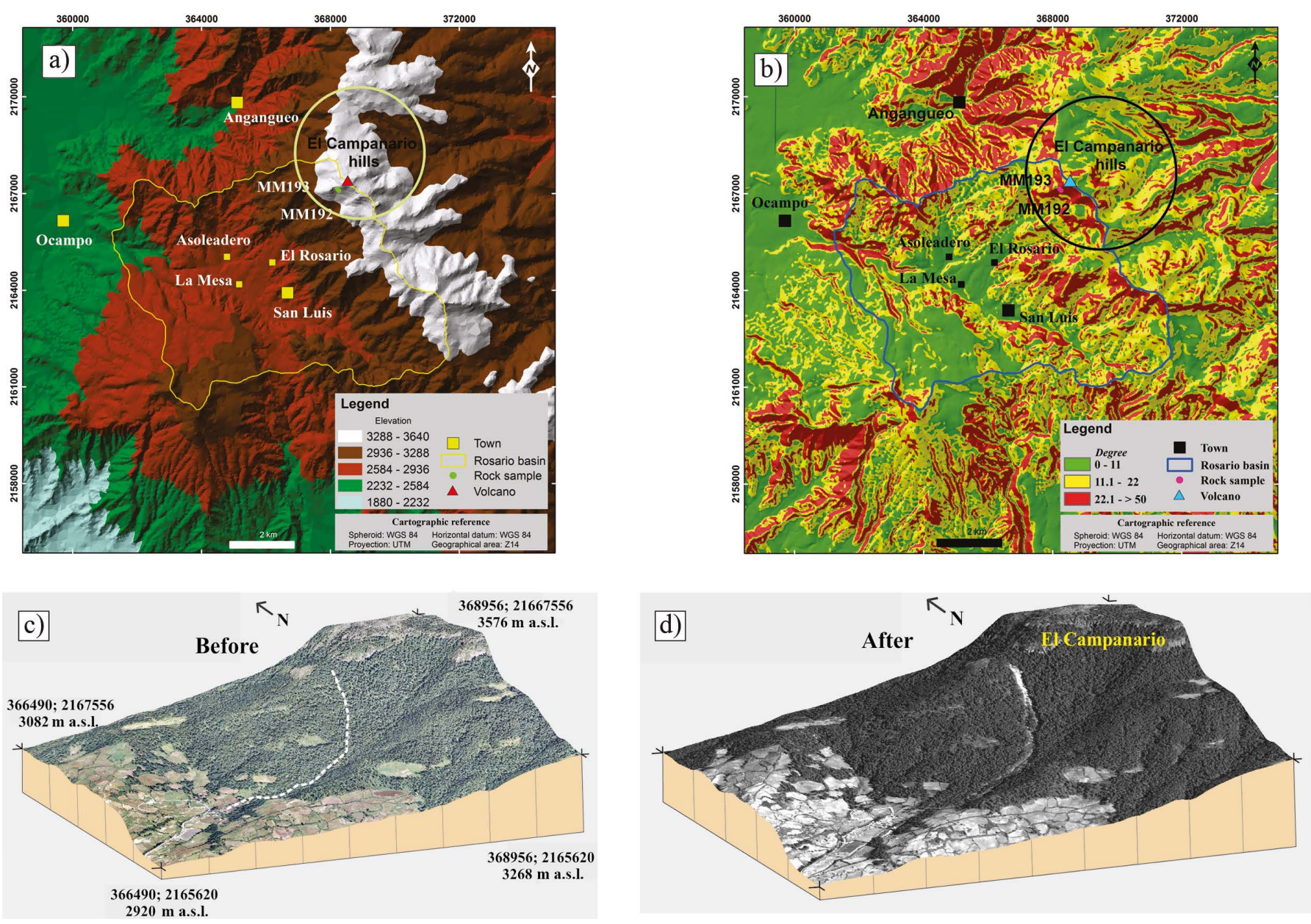

Figure 4. a) Hypsometric map of El Rosario basin showing the difference of altitudes in the study area. b) Slope map showing the grade of the slope at El Campanario hill and its influence on hillside instability. c) Photogrammetric image from 2005 showing the study area before the slope failure. The route followed by the debris flow is shown with a white dotted line. d) Satellite image Spot 6 (February 2015) showing the debris flow in the Monarch Butterfly sanctuary developed in 2010. We can observe its magnitude, length and area of distribution.

andesite sampled at $3475 \mathrm{~m}$ a.s.l. (MM193), highly altered andesites at the debris flow source zone (MM192). At outcrop scale, the collected samples show substantial differences in effective porosity $\left(\eta_{e}\right)$, permeability $(k)$, and density. Table 2 summarizes the properties of fresh and altered samples, all results being given as an average value, with their corresponding standard deviation.

The strength of a rock is closely related to its texture and structure, and fracture mode and fracture evolution depends on the distribution and size of grains, minerals and pores. Figure 6 shows the stress-strain behavior of both MM192 and MM193 samples: the strength of the fresh sample ( 60 MPa, MM193 from 1 to 10), in comparison to fresh sample with preexisting damage (microcrack) ( 116 MPa, MM193-11) is abnormally lower, probably because both the orientation and the characteristics of microcracks (e.g. roughness, cementation grade) (see Figure 6c) contributed to the increase in the final strength. On the contrary, as shown in Figure 4a, the slope of the stress-strain curves ( $E$ values) is similar. Figure $6 c$ shows the failure surface, developed in sample MM192-02, MM193-11, and MM-193-02 specimens. As expected, in the most homogeneous specimens, cracks developed in the direction of the maximum applied shear stress, while in the specimens with preexisting damage the cracks developed exactly on the preexisting microcracks. Moreover, cracks of the completely altered
Table 2. Summary of physical and mechanical properties of fresh and completely altered samples (all values are given as an average, with their corresponding standard deviation).

\begin{tabular}{ccc}
\hline ID & MM193 & MM192 \\
\hline$\gamma_{\text {He }}\left(\mathrm{g} / \mathrm{m}^{3}\right)$ & $2.61 \pm 0.002$ & $2.52 \pm 0.0007$ \\
$\rho_{\text {He }}\left(\mathrm{g} / \mathrm{m}^{3}\right)$ & $2.807 \pm 0.001$ & $2.54 \pm 0.02$ \\
$\boldsymbol{k}(\mathrm{mD})$ & $0.262 \pm 0.319$ & 393.71 \\
$\boldsymbol{k}\left(\mathrm{m}^{2}\right)$ & $2.58 \mathrm{E}-16 \pm 3.15 \mathrm{E}-16$ & $3.88 \mathrm{E}-13$ \\
$\boldsymbol{\eta} \mathbf{e H e}(\%)$ & $12.06 \pm 2.46$ & 59.88 \\
$\boldsymbol{\eta} \mathbf{e}(\%)$ & $10.04 \pm 2.16$ & \\
$\boldsymbol{\eta}_{\mathrm{T}}(\%)$ & $17.14 \pm 2.54$ & 60.93 \\
$\boldsymbol{\sigma s}(\mathrm{MPa})$ & $63.51 \pm 19.67$ & $0.26 \pm 0.03$ \\
$\mathbf{E}(\mathrm{GPa})$ & $26.7 \pm 6.40$ & - \\
$\boldsymbol{v}(-)$ & 0.38 & - \\
$\boldsymbol{\sigma t}(\mathrm{MPa})$ & $6.3 \pm 1.24$ & - \\
\hline
\end{tabular}

Abbreviations are: $\gamma \mathrm{He}=$ bulk density by helium pycnometer; $\rho \mathrm{He}=$ real density by helium pycnometer; $k=$ permeability; $\eta \mathrm{He}=$ effective porosity by helium pycnometer; $\eta \mathrm{e}=$ effective porosity; $\eta_{\mathrm{T}}=$ total porosity; $\sigma \mathrm{s}=$ uniaxial compressive strength; $\mathrm{E}=$ Young modulus; $\mathrm{v}=$ Poisson ratio; $\sigma \mathrm{t}=$ tensile strength. 

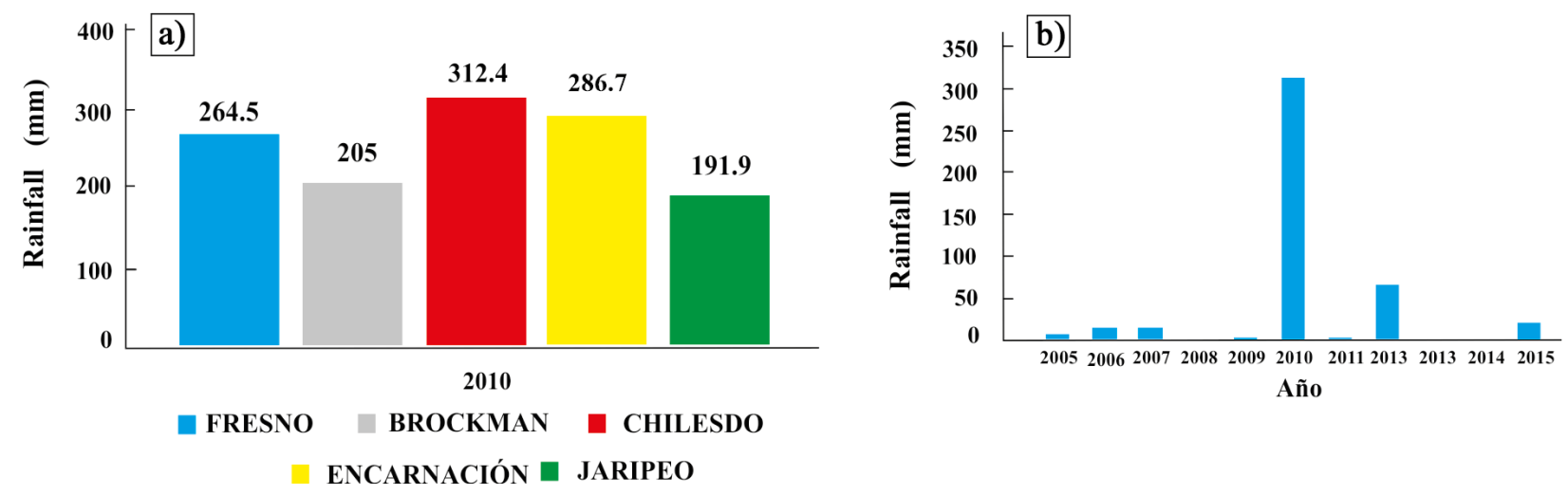

Figure 5. a) Histogram of rainfall in February 2010 recorded in five hydrometeorological stations in the Sierra de Angangueo. Values $>190$ mm considered as atypical are observed for the month of February. b) Pluvial precipitation values recorded at the Chilesdo station, located just 14 km from the Monarch Butterfly Sanctuary.

samples are characterized by conical and vertical shearing, mode of fracture associated or described for porous or granular materials.

\section{DISCUSSION}

According to the geomechanical results of the fresh and altered rock samples (stress-strain, porosity, permeability, compressive strength) (see Table 2), the debris flow deposit contains particles ranging from $2 \mathrm{~mm}$ to metric-sized blocks of fresh rock. The fraction of fine particles $<2 \mathrm{~mm}$ was provided by the altered rocks. Therefore, at the time of the debris flow emplacement it was channeled and had a medium mobility typical for cohesive flows with a matrix (SánchezNúñez et al. 2015). The maximum distance traveled by the debris flow was about $1.5 \mathrm{~km}$ prior to stop.

Frolova et al. (2019) found similar geological settings at the largest geothermal fields in Kamchatka. They argued that thermal water changes the mineral composition of the original rock (andesite) promoting landslides. Moon et al. (2005) presented similar conditions at White Island (stratovolcano of New Zealand). They showed the susceptibility to crater wall collapse due to a very steep slope and the significantly hydrothermally altered rock. Other authors, such as Jazouli et al. (2020), Upton et al. (2018) and Reid et al. (2001), presented considerations relevant to slope stability assessment related to
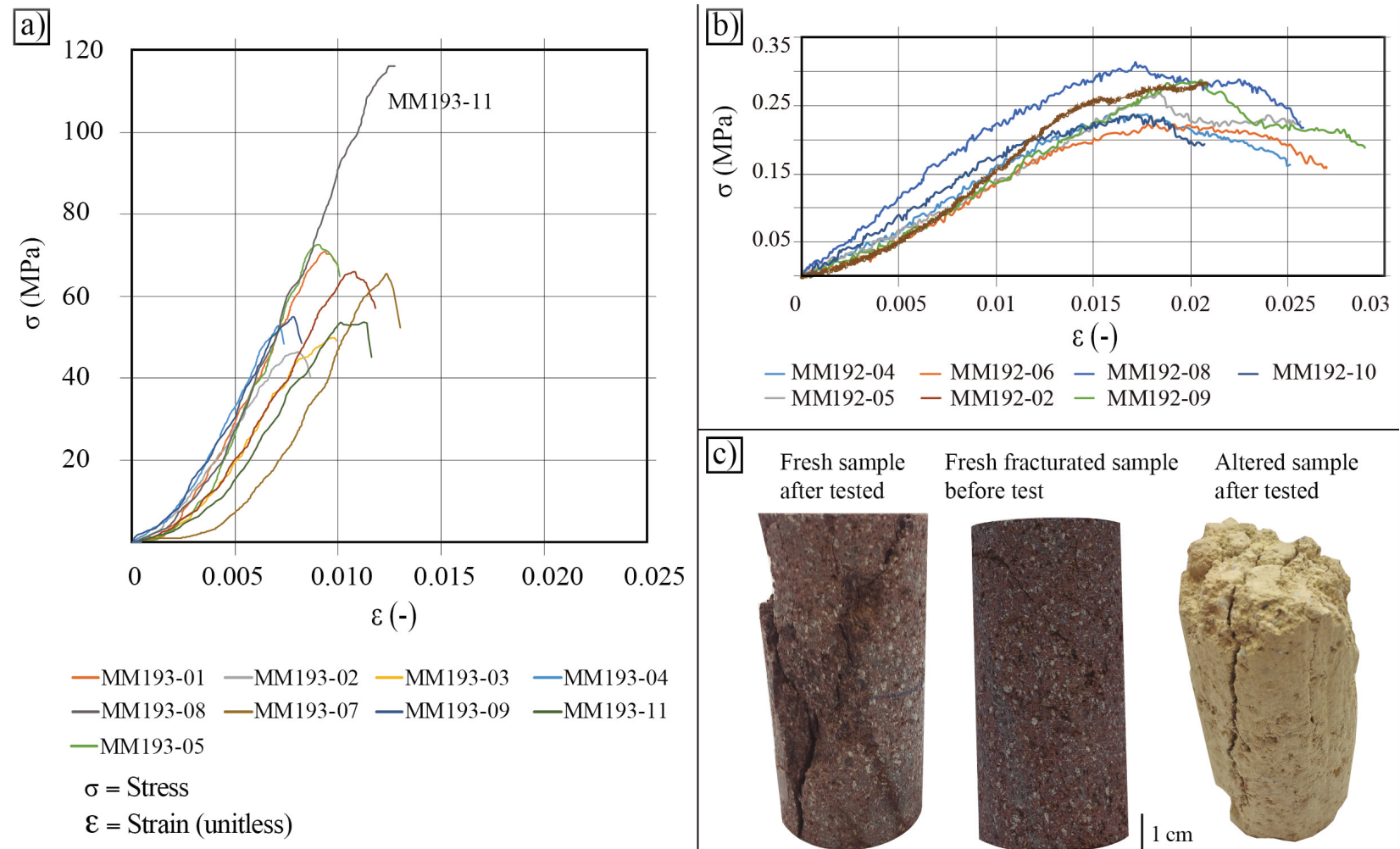

c)

$\begin{array}{ll}\begin{array}{l}\text { Fresh sample } \\ \text { after tested }\end{array} & \begin{array}{l}\text { Fresh fracturated sample } \\ \text { before test }\end{array}\end{array}$

Altered sample
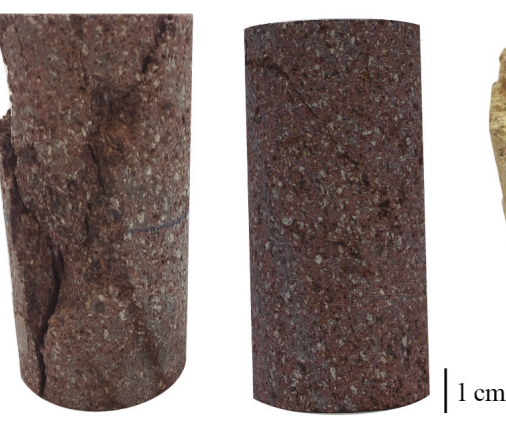
after tested

MM193-02

MM193-11

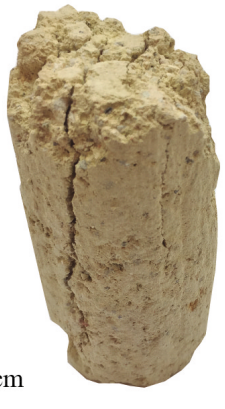

MM192-02

Figure 6. Stress-strain curves for a) fresh and b) completed altered lavas. c) Images of samples deformed to failure during uniaxial compressive tests (MM193-02, MM192-02). Fresh fractured sample before test, which shows the maximum strength is also included (MM193-11). 
rock properties and slope gradient. They performed a geomechanical study and characterized the strong (fresh) and weak (altered) rocks in the basin of the Oum Er Rbia river (Morocco), the Alpine Fault (New Zealand) and from Mount Rainier (Washington).

Rainfall is one of the most important triggering factors for landslides worldwide; this is shown by many studies such as those carried out by Rong et al. (2020) in Shuicheng Country, China; Zhang et al. (2019) in Shaanxi Province, China, Saucedo et al. (2008) in Nevado de Colima volcano, Caballero et al. (2006) in Chiapas, Mexico, Capra et al. (2003) in Puebla, Mexico. Polemio and Petrucci (2000) presented an overview of international research on rainfall as a landslide triggering factor.

According to Table 2, we observe a clear decay of the properties between fresh and completely altered lava is visible. Effective porosity $\left(\eta_{\mathrm{e}}\right)$, permeability $(k)$, and uniaxial compressive strength (UCS) changes from approximately 12 to $60 \%, 0.26$ to $393.71 \mathrm{mD}$, and 63 to $0.28 \mathrm{MPa}$, respectively. Values of the fresh samples are in the range of similar volcanic rocks reported elsewhere (e.g., Pola et al., 2014; Heap et al., 2014; Farquharson et al., 2015), while the properties of the completely altered samples have not been placed in a global context because the degree of alteration has not been analyzed in detail in this work. In any case, a literature review suggests that strength values are within the range of those for hard soils (e.g., Avşar et al., 2015) and weak rocks.

As described in literature (e.g., Palchik and Hatzor, 2002) porosity (effective and total) is an important parameter of rock materials which directly determines their mechanical strength. As graphically described in Figure 4c, the intense hydrothermal alteration could completely modify all physical properties, including rock fabric, porosity, density, and consequently mechanical behavior.

According to Benavente et al. (2015), the fluid permeability could be classified into four different groups: very low ( $k$ value under $1 \mathrm{mD}$ ), low $(1<k<100 \mathrm{mD})$, permeable $(100<k<10000 \mathrm{mD})$, and high
( $k$ values higher than $10000 \mathrm{mD}$ ). The altered and fresh samples could be classified as permeable and of very low permeability, respectively (see Table 2 and Figure 7). The five-point reciprocal mean pressure test $\left(1 / \mathrm{P}_{\text {mean }}\left[\right.\right.$ Abs Atm $\left.\left.{ }^{-1}\right]\right)$ is efficient not only for characterizing the permeability, but also for understanding the very complex interconnected pore structure and the effect of some interconnected pores that contribute very little to the flow (e.g., dead-end pores, see Sander et al., 2017 for a good review). In this way, if we want to respect always the Darcy's law for ideal horizontal laminar flow of gas under steady state isothermal conditions, in certain mechanisms of flow such as diffusion and dispersion it is important to pay attention to the effects of this particular type of pores. Particularly, the dispersion mechanism is due to the differences in the fluid flow velocity fields in the fracture networks, caused mainly by the variations in trace lengths, orientations and apertures of the interconnected pores and the fractures.

Values of $k$ of the specimens range from 0.012 to $1.03 \mathrm{mD}$ for fresh specimens to 396 to $409 \mathrm{mD}$ for completely altered specimens (Figure 7). If we compare these results with those obtained by the implementation of the same methodology on different rocks, we observe that permeability values of the completely altered samples are similar to the values obtained for very porous materials such as pumice rocks. On the contrary, large differences are observed in the distribution of the five-point reciprocal mean pressures. It should be remembered that these distributions could be associated to the geometric and physical characteristics (e.g., tortuosity, roughness) of the microstructural elements of the specimens. In turn, permeability values of fresh samples are similar to the values obtained for dense but microfractured materials, as well as for hydrothermally altered rocks (Figure 7). However, a considerable increase in permeability values and therefore in effective porosity between MM193 and MM192 samples could be easily identified.

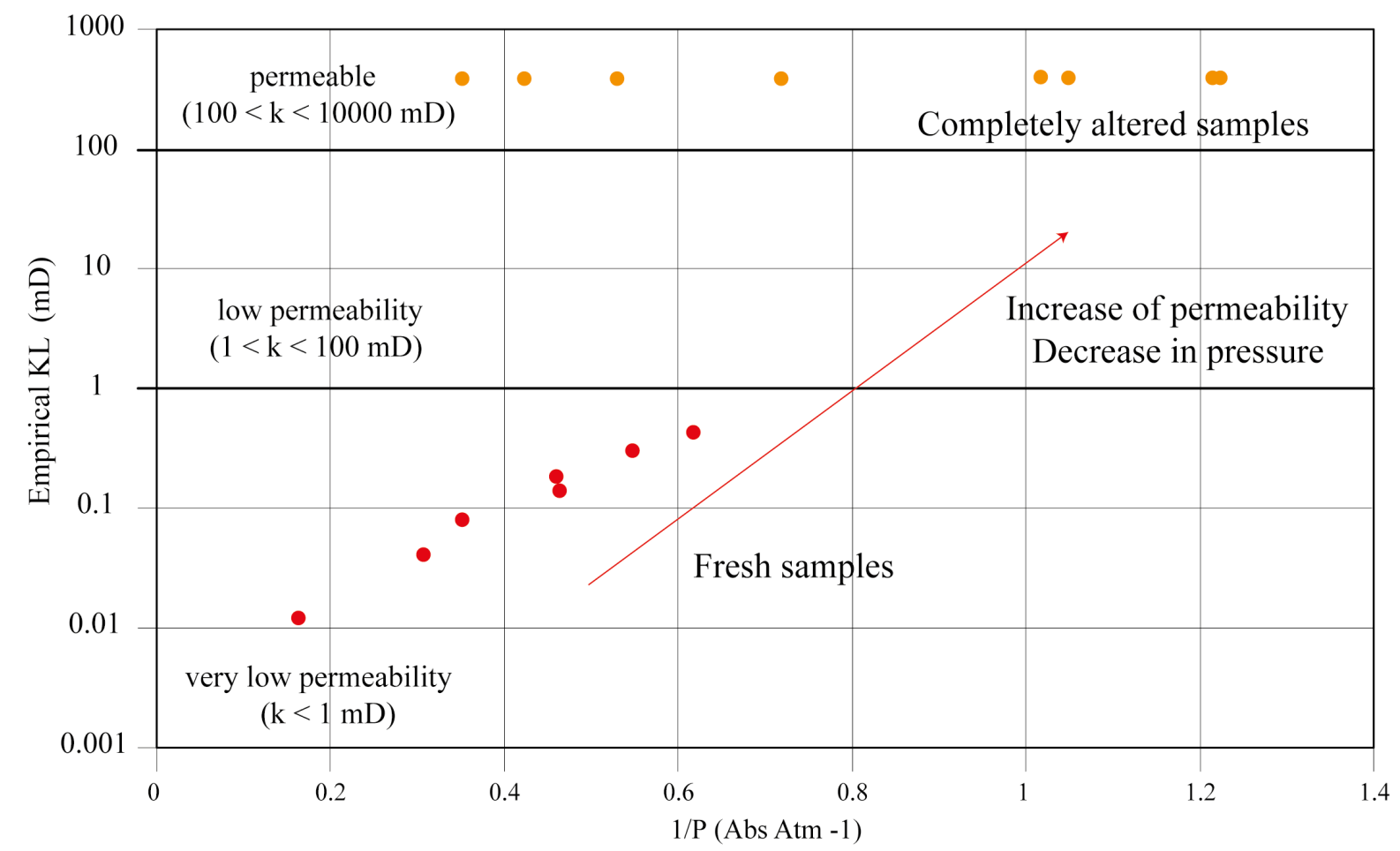

Figure 7. Empirical permeability of fluid $(\mathrm{mD})$ versus reciprocal mean pressure (1/Pmean [Abs Atm-1]). Solid black lines indicate the permeability classification according to that discussed in Benavente et al. (2015), while red and orange solid circles indicate the position of values of the fresh (MM193) and completed altered samples (MM192), respectively. 


\section{CONCLUDING REMARKS}

We investigated the differences in physical and mechanical properties between fresh (MM193) and completely altered (MM192) lava samples. The main findings are as follows:

The intense hydrothermal alteration has completely modified all physical properties, including porosity, density, and consequently mechanical behavior of the fresh lava MM193.

The strength of fresh samples is in the range of strength of similar andesite rocks, while the strength of fresh sample with preexisting damage (microcrack) is abnormally higher, probably because both the orientation and the characteristics of microcracks (e.g., roughness, cementation grade) are contributing to the increase in the final strength.

The strength of altered samples is very low; it is within the range of strength values of a weak rock. Values obtained in dry conditions indicate that strength decreases about $99 \%$ from fresh to completely altered sample (from 70 to $0.26 \mathrm{MPa}$ ).

Permeability values change drastically between fresh and altered samples. Mechanism of flow such as diffusion and dispersion are graphically described by the distribution of the reciprocally mean pressure.

The conditioning factors involved in the generation of the debris flow in El Campanario were: a substrate altered by hydrothermalism, the slope of the land $\left(>35^{\circ}\right)$, and the morphology of the slope. The triggering factor was the unusual rainfall ( $>144 \mathrm{~mm}$ on a single day) in February 2010.

\section{ACKNOWLEDGMENTS}

We dedicate this article to the memory of Dr. Víctor Hugo Garduño Monroy. He was a dear friend and extraordinary teacher who sowed the seed of passion for geology in many generations of students ... we will always miss him! This work was funded by the SIP 20200842 Project of the Instituto Politécnico Nacional. We want to thank the members of the Unidad de Petrofísica of Escuela Nacional de Estudios SuperioresUnidad Morelia, Universidad Nacional Autónoma de México (UNAM) for carrying out the laboratory tests. We thank the guest editors Isabel Israde Alcántara, Instituto de Investigaciones en Ciencias de la Tierra (INICIT), Universidad Michoacana de San Nicolás de Hidalgo, and José Luis Macías V., Instituto de Geofísica, UNAM. Finally, we gratefully acknowledge thorough reviews by Dora Carreón Freyre and an anonymous reviewer which resulted in significant improvements to the original manuscript.

\section{REFERENCES}

Aladejare, A.E. Wang, Y., 2016, Evaluation of rock property variability: Georisk: Assessment and Management of Risk for Engineered Systems and Geohazards, http://dx.doi.org/10.1080/17499518.2016.1207784

Alcantara-Ayala, I., López-García, J., Garnica, R.J., 2012, On the landslide evento in 2010 in the Monarch Butterfly Biosphere Reserve, Angangueo, Michoacán, Mexico: Landslides 9: 263-273, DOI: 10.1007/ s10346-011-0291-7

ASTM, 2001a, D4543-01 Standard Practices for Preparing Rock Core Specimens and Determining Dimensional and Shape Tolerances: West Conshohocken, PA, USA, American Society for Testing and Materials (ASTM).

ASTM, 2001b, D3967-95a(2001) Standard Test Method for Splitting Tensile Strength of Intact Rock Core Specimens: West Conshohocken, PA, USA, American Society for Testing and Materials (ASTM).

ASTM, 2002a, D2938-95(2002), Standard Test Methods for Unconfined Compressive Strength of Intact Rock Core Specimens: West Conshohocken, PA, USA, American Society for Testing and Materials (ASTM).
ASTMb 2002b, D3148-02, Standard Test Method for Elastic Moduli of Intact Rock Core Specimens in Uniaxial Compression: West Conshohocken, PA, USA, American Society for Testing and Materials (ASTM).

ASTM, 2013, D4525-13e2, Standard Test Method for Permeability of Rocks by Flowing Air: West Conshohocken, PA, USA, American Society for Testing and Materials (ASTM).

ASTM, 2014, D5550-14, Standard Test Method for Specific Gravity of Soil Solids by gas Pycnometer: West Conshohocken, PA, USA, American Society for Testing and Materials (ASTM).

ASTM, 2021, D7263-21, Standard Test Methods for Laboratory Determination of Density (Unit Weight) of Soil Specimens: West Conshohocken, PA, USA, American Society for Testing and Materials (ASTM)..

Avşar, E., Ulusay, R., Mutlutürk, M., 2015, An experimental investigation of the mechanical behavior and microstructural features of a volcanic soil (Isparta, Turkey) and stability of cut slopes in this soil: Engineering Geology, 189, 68-83, https://doi.org/https://doi.org/10.1016/j.enggeo.2015.01.027

Benavente, D., Pla, C., Cueto, N., Galvañ, S., Martínez-Martínez, J., García-delCura, M.A., Ordóñez, S., 2015, Predicting water permeability in sedimentary rocks from capillary imbibition and pore structure: Engineering Geology, 195, 301-311, https://doi.org/10.1016/j.enggeo.2015.06.003

Bubeck, A., Walker, R.J., Healy, D., Dobbs, M., Holwell, D.A., 2017, Pore geometry as a control on rock strength: Earth and Planetary Science Letters, 457, 38-48. https://doi.org/10.1016/j.epsl.2016.09.050

Caballero, L., Macías J.L., García-Palomo, A., Saucedo, G.R, Borselli, L., Sarocchi, D., Sánchez-Núñez, J.M., 2006, The September 8-9, 1998 Rain- triggered flood events at Motozintla, Chiapas, México: Natural Hazards, 39, 103-126, DOI 10.1007/s11069-005-4987-7.

Campa, M.F., Coney, P.J., 1983, Tectono-stratigraphic terranes and mineral resource distributions in Mexico: Canadian Journal of Earth Sciences, 20(6), 1040-1051. https://doi.org/10.1139/e83-094

Campa, M.F., Ramirez, E., Coney, P.J., 1981, Conjuntos estratotectónicos de la Sierra Madre del Sur, región comprendida entre los estados de Guerrero, Michoacán, México y Morelos: Boletín de La Sociedad Geológica Mexicana, 42(1-2), 26-67.

Capra, L., Hubp, L., Hernández, N.D., 2003, Fenómenos de remoción en masa en el poblado de Zapotitlán de Méndez, Puebla: relación entre litología y tipo de movimiento: Revista Mexicana de Ciencias Geológicas. 20(2), 95-106.

Demant, A., 1978, Características del eje neovolcánico Transmexicano y sus problemas de Interpretación: Revista del Instituto de Geología, Universidad Nacional Autónoma de México, 2, 172-187.

Dikau, R., Brundsen, D., Schrott, L., Ibsen, M., 1996, Landslide recognition, identification, movement and causes: Chichester, Wiley \& Sons, $251 \mathrm{pp}$.

DOF (Diario Oficial de la Federación), 2010, Declaratoria de desastre natural por la ocurrencia de lluvia severa los días 4 y 5 de febrero de 2010, en 3 municipios del Estado de Michoacán de Ocampo: Diario Oficial de la Federación, 25 de febrero de 2010: Retrieved from de http://dof.gob.mx/

EN, 2006, EN 1936:2006, Natural stone test methods. Determination of real density and apparent density, and of total and open porosity: British Standards Institution (BSI) Standards Publication, $14 \mathrm{pp}$.

Farquharson, J., Heap, M.J., Varley, N.R., Baud, P., Reuschl, T., 2015, Permeability and porosity relationships of edifice-forming andesites: A combined field and laboratory study: Journal of Volcanology and Geothermal Research, 297, 52-68, https://doi.org/10.1016/j.jvolgeores.2015.03.016

Ferrari, L., Orozco-Esquivel, T., Manea, V., Manea, M., 2012, The dynamic history of the Trans-Mexican Volcanic Belt and the Mexico subduction zone: Tectonophysics, 522-523, 122-149. https://doi.org/10.1016/j. tecto.2011.09.018

Frolova, J., Chernov, M., Rychagov, S., Kuznetsov, R., Surovtseva, K., 2019, Alteration of volcanic rocks and changes in physical-mechanical properties on the South-Kambalny termal field (South Kamchatka): E3S Web of Conferences 98,08002, WRI-16, https://doi.org/10.1051/ e3sconf $/ 20199808002$

H. Ayuntamiento Constitucional de Angangueo, Michoacán, 2014, Atlas de riesgos naturales de Angangueo, Michoacán, México: Morelia, Mich., Periódico Oficial del Gobierno Constitucional del Estado de Michoacán de Ocampo, october 31, 2014, tomo CXL, num. 67, 35 pp.

Heap, M.J., Kennedy, B.M., 2015, Exploring the scale-dependent permeability of fractured andesite: Earth and Planetary Science Letters, 447, 139-150, https://doi.org/10.1016/j.epsl.2016.05.004

Heap, M.J., Lavallée, Y., Petrakova, L., Baud, P., Reuschlé, T., Varley, N.R., 
Dingwell, D.B., 2014, Microstructural controls on the physical and mechanical properties of edifice-forming andesites at Volcán de Colima, Mexico: Journal of Geophysical Research: Solid Earth, 119(4), 2925-2963. https://doi.org/10.1002/2013JB010521

Hernández-Bernal, M.D.S., Corona-Chávez, P., Solís-Pichardo, G., Schaaf, P., Solé-Viñas, J., Molina, J.F., 2016, Miocene andesitic lavas of Sierra de Angangueo: A petrological, geochemical, and geochronological approach to arc magmatism in Central Mexico: International Geology Review, 58(5), 603-625, DOI: 10.1080/00206814.2015.1101356

INEGI (Instituto Nacional de Estadística y Geografía), 2009, Prontuario de información geográfica municipal de los Estados Unidos Mexicanos: Angangueo, Michoacán de Ocampo: Clave geoestadística 16005, 9 pp.

INEGI (Instituto Nacional de Estadística y Geografía), 2010, Información topográfica digital E14A26 Mineral de Angangueo, escala 1:50 000, serie III: Available at: https://www.inegi.org.mx/app/mapas/.

ISRM (International Society on Rock Mechanics), 2007, The Complete ISRM Suggested Methods for Rock Characterization, Testing and Monitoring: 1974-2006, in Ulusay, R., Hudson, J.A. (eds.), Suggested Methods Prepared by the Commission on Testing Methods: Ankara, Turkey, Commission on Testing Methods, International Society of Rock Mechanics, $628 \mathrm{pp}$.

Jazouli, A., Barakat, A., Khellouk, A., 2020, Geotechnical studies for Landslide susceptibility in the high basin of the Oum Er Rbia river (Morocco): Geology, Ecology, and Landscapes, DOI: 10.1080/24749508.2020.1743527

Kim, K.S., Song, Y.S., 2015, Geomechanical and Geotechnical characteristics of landslides in Korea under various geological conditions: Journal of Mountain Science 12(5), 1267-1280. DOI: 10.1007/s11629-014 -3108-z

López-García, J., Alcántara-Ayala, I., 2012, Land-use and hillslope instability in the Monarch Butterfly Biosphere Reserve, Central Mexico: Land Degradation \& Development, 23, 384-397, DOI: 10.1002/Idr.2159

Maeda, H., Sasaki, T., Furuta, K., Takashima, K., Umemura, A., Kohno, M., 2012, Relationship between landslide, geologic structures, and hydrothermal alteration zones in the Ohekisawa-Shikerebembetsugawa landslide area, Hokkaido, Japan: Journal of Earth Science and Engineering 2, 317-327.

Mikoš, M., Casagli, N., Yin, Y., Sassa, K. (eds), 2017, Advancing culture of living with landslides, diversity of landslide forms: v.4, Diversity of Landslide Forms: Springer International Publishing, 692 pp., DOI 10.1007/978-3-319-53485-5

Moon, V., Bradshaw, J., Smith, R., de Lange, W., 2005, Geotechnical characterization of stratocone crater wall sequences, White Island Volcano, New Zealand: Engineering Geology, 81, 146-178

Nadim, F., Kjekstad, O., Peduzzi, P., Herold, C., Jaedicke, C., 2006, Global landslide and avalanche hotspots: Landslides, 3(2), 159-174. doi:10.1007/ s10346-006-0036-1

Ostrooumov, M., 2014, Mineralogía de los yacimientos hidrotermales de mediana temperatura en Angangueo, Michoacán, México: www. researchgate.net/publication/269986955

Palchik, V., Hatzor, Y.H., 2002, Crack damage stress as a composite function of porosity and elastic matrix stiffness in dolomites and limestones: Engineering Geology, 63(3-4), 233-245. https://doi.org/10.1016/ S0013-7952(01)00084-9

Pasquarè, G., Ferrari, L., Garduño-Monroy, V.H., Tibaldi, A., Vezzoli, L., 1991, Geology of the central sector of the Mexican Volcanic Belt, States of Guanajuato and Michoacán: Geological Society of America Map and Chart Series MCH072, map and text, 1 map, 22 pp.

Persichillo, M.G., Bordoni, M., Meisina, C., Bartelletti, C., Barsanti, M., Giannecchini, R., Avarzi, G.D., Galanti, Y., Cevasco, A., Brandolini, P., Galve, J.P., 2016, Shallow landslides susceptibility assessment in different environments: Geomatics, Natural Hazards and Risk, 8(2), 748-771, doi: $10.1080 / 19475705.2016 .1265011$
Pola, A., Crosta, G.B., Fusi, N., Castellanza, R., 2014, General characterization of the mechanical behaviour of different volcanic rocks with respect to alteration: Engeneering Geology, 169, 1-13, https://doi.org/10.1016/j. enggeo.2013.11.011

Polemio, M., Petrucci, O., 2000, Rainfall as a landslide triggering factor: an overview of recent international research, in Bromhead, E., Dixon, N., Ibsen, M.L Landslides: in research, theory and practice, v. 3, 8th International Symposium on Landslides, Cardiff, june 2000: London, Thomas Telford Ltd., 6 pp

Reid, M.E., Sisson, T.W., Brien, D.L., 2001, Volcano collapse promoted by hydrothermal alteration and edifice shape, Mount Rainier, Washington: Geological Society of America, 29(9), 779-782

Rong, G., Li, K., Han, L., Alu, S., Zhang,J., Zhang, Y., 2020, Hazard Mapping of the Rainfall-Landslides Disaster Chain Based on GeoDetector and Bayesian Network Models in Shuicheng County, China: Water, 12(9), 2572, doi:10.3390/w12092572

Sánchez-Núñez, J.M., Macías, J.L., Saucedo, R., Zamorano, J.J., Novelo, D., Mendoza, M., Torres-Hernández, R., 2015, Geomorphology, internal structure and evolution of alluvial fans at Motozintla, Chiapas, Mexico: Geomorphology, 230, 1-12 DOI:10.1016/j.geomorph.2014.10.003

Sander, R., Pan, Z., Connell, L.D., 2017, Laboratory measurement of low permeability unconventional gas reservoir rocks: A review of experimental methods: Journal of Natural Gas Science and Engineering, 37, 248-279, https://doi.org/10.1016/j.jngse.2016.11.041

Saucedo, R., Macías, J.L., Sarocchi, D., Bursik, M., Rupp, B., 2008, The raintriggered Atenquique volcaniclastic debris flow of October 16, 1955 at Nevado de Colima Volcano, Mexico: Journal of Volcanology and Geothermal Research, 173, 69-83.

SGM (Servicio Geológico Mexicano), 2000, Carta geológico-minera Angangueo, clave E14A26, Estado de México y Michoacán de Ocampo, escala 1:50 000: CITY, COUNTRY, EDITORIAL, 1 map.

Upton, P., Koons, P., Samuel G. Roy, S., 2018, Rock failure and erosion of a fault damage zone as a function of rock properties: Alpine Fault at Waikukupa River, New Zealand: Journal of Geology and Geophysics, DOI: $10.1080 / 00288306.2018 .1430592$

Varnes, D.J., 1978, Slope movements types and processes, in Schuster R.L., Krizek R.J., (ed.), Landslides analysis and control: Washington D. C, National Academy Press, Transportation Research Board Special Report 176, 9-33.

Wieczorek, G.F., 1987, Effect of rainfall intensity and duration on debris flows in central Santa Cruz Mountains, California, in Costa, J.E, Wieczorek, G.F., Debris Flows/Avalanches: Process recognition and Mitigation: Geological Society of America, Reviews in Engineering Geology, v. 7, 93-104.

Zhang, K., Wang, S., Bao, H., Zhao, X., 2019, Characteristics and influencing factors of rainfall-induced landslide and debris flow hazards in Shaanxi Province, China: Natural Hazards and Earth System Sciences, 19, 93-105, https://doi.org/10.5194/nhess-19-93-2019

Manuscript received: february 14, 2021

Corrected manuscript received: september 15, 2021

Manuscript accepted: october 12, 2021 